\title{
Pengaruh Marketing Mix Terhadap Keputusan Pembelian (Studi Kasus pada Minyeuk Pret di Kota Banda Aceh)
}

\author{
RAHMI \\ Program Studi Manajemen, Fakultas Ekonomi, Universitas Serambi Mekkah, \\ Jalan Batoh, Lueng Bata, Kota Banda Aceh, Provinsi Aceh, Indonesia \\ rahmi@serambimekkah.ac.id \\ NELLY * \\ Program Studi Manajemen, Fakultas Ekonomi, Universitas Serambi Mekkah, \\ Jalan Batoh, Lueng Bata, Kota Banda Aceh, Provinsi Aceh, Indonesia \\ nelly@serambimekkah.ac.id
}

\section{Article's history:}

Received 7 February 2020; Received in revised form 12 July 2020; Accepted 16 August, 2020;

Published 30 August 2020. All rights reserved to the Lembaga Otonom Lembaga Informasi dan Riset Indonesia (KITA INFO dan RISET).

Suggested citation:

Rahmi, R., Nelly, N. 2020. Pengaruh Marketing Mix Terhadap Keputusan Pembelian (Studi Kasus pada Minyeuk Pret di Kota Banda Aceh). JEMSI (Jurnal Ekonomi, Manajemen, dan Akuntansi), Volume 6 (2): 52-58. DOI: https://doi.org/10.35870/jemsi.v6i1.338.

\section{ABSTRAK:}

Penelitian ini bertujuan untuk mengetahui Pengaruh Marketing Mix Terhadap Keputusan Pembelian (Studi Kasus Pada Minyeuk Pret Di Kota Banda Aceh). Populasi dalam penelitian ini adalah konsumen yang menggunakan parfum beraroma khas daerah Aceh, yang berada di Kota Banda Aceh. Sampel dalam penelitian ini adalah 100 responden. Dalam menganalisis data untuk penelitian ini digunakan regresi linear berganda (Multiple Linear Regression). Hasil penelitiannya menunjukkan bahwa produk, harga dan promosi berpengaruh signifikan terhadap pengambilan keputusan pembelian Minyeuk Pret di Kota Banda Aceh, hal ini dibuktikan bahwa produk, harga dan promosi merupakan faktor yang mempengaruhi pengambilan keputusan pembelian sebesar $78,5 \%$ dan sisanya yaitu sebesar $21,5 \%$ dijelaskan oleh variabel lain diluar dari pada penelitian ini, misalnya citra merek, perilaku konsumen dan lain-lain. Berdasarkan hasil analisis regresi linier berganda bahwa dari ketiga variabel yang diteliti, ternyata variabel promosi (X3) mempunyai pengaruh paling dominan terhadap pengambilan keputusan pembelian Minyeuk Pret di Kota Banda Aceh, dengan nilai koefisien sebesar 0,799, kemudian diikuti oleh variabel harga (X2) dengan nilai koefisien sebesar 0,394, dan diikuti oleh variabel produk (X1) dengan nilai koefisien sebesar 0,143.

Kata Kunci: Marketing Mix; Keputusan Pembelian.

JEL Classification: M00; M31.

\section{PENDAHULUAN}

Peningkatan jumlah penduduk semakin meningkat, hal ini berdampak pada semakin meningkat juga jumlah kebutuhan masyarakatnya, baik itu kebutuhan akan barang ataupun jasa. Dengan kondisi yang demikian, tentu saja sangat menguntungkan bagi dunia usaha. Kesempatan ini dapat dimanfaatkan oleh pengusaha untuk membuka usaha atau bisnis dalam upaya memenuhi kebutuhan masyarakat tersebut. Menurut Kotler dan Amstrong (2011:63), bauran pemasaran (Marketing Mix) adalah sarana taktis perusahaan untuk menentukan positioning yang kuat dalam pasar sasaran.

Keputusan pembelian merupakan kegiatan individu yang secara langsung terlibat dalam pengambilan keputusan untuk melakukan pembelian terhadap produk yang ditawarkan oleh penjual. Kotler dan Amstrong (2011:129) keputusan pembelian konsumen adalah perilaku pembelian akhir dari konsumen baik individual maupun rumah tangga, yang membeli barang-branag dan jasa untuk konsumsi pribadi. Minyeuk prêt merupakan usaha kreativitas yang dikelola oleh anak muda Aceh. Penamaan Minyeuk Pret diangkat dari bahasa Aceh, menurut sejarah orang tua Aceh zaman dahulu, penyebutan parfum itu disebut dengan Minyeuk Pret (Minyak yang disemprot). Parfum Minyeuk Pret merupakan salah satu produk lokal yang mempunyai aroma khas Aceh yang 
menunjukkan kearifan lokal masyarakat Aceh seperti aroma Coffee, Seulanga, Jeumpa dan Meulu. Berdasarkan uraian dari latar belakang diatas, maka penelitian ini disusun untuk mengetahui pengaruh Bauran Pemasaran Terhadap Keputusan Pembelian (Studi Kasus Pada Minyeuk Pret) di Kota Banda Aceh.

\section{TINJAUAN KEPUSTAKAAN}

\section{Pemasaran}

Pemasaran merupakan salah satu dari kegiatan pokok dalam bisnis selalu ada kompetisi antar perusahaan dan akan terus berusaha untuk memperluas pasar dan mempertahankan eksistensi perusahaan. Aktivitas perusahaan dalam pemasaran ini bertujuan untuk menentukan arah perusahaan agar mampu bersaing dalam dunia persaingan yang makin ketat. Pemasaran merupakan unsur penting dalam perusahaan untuk menentukan sukses atau tidaknya suatu bisnis. Pemasaran adalah prosessosial yang didalamnya terdiri dari individu dan kelompok yang bertujuan mendapatkan apa yang mereka butuhkan dan inginkan dengan menciptakan, menawarkan dan secara bebas mempertukarkan produk yang bernilai dengan pihak lain (Kotler, 2009). Stanton menyatakan bahwa pemasaran adalah suatu sistem keseluruhan dari kegiatan-kegiatan bisnis yang ditujukan untuk merencanakan, menentukan harga, mempromosikan dan mendistribusikan barang dan jasa memuaskan kebutuhan baik kepada pembeli yang ada maupun pembeli potensial. (Dharmmesta dan Irawan, 2001) pemasaran memiliki dua hal, pertama pemasaran merupakan filosofi, sikap, perspektif dan orientasi manajemen yang menekankan kepada kepuasan konsumen. Kedua, pemasaran adalah sekumpulan aktivitas yang digunakan untuk mengimplementasikan filosofi tersebut.

\section{Konsep Pemasaran}

Konsep pemasaran adalah falsafah manajemen pemasaran mengatakan bahwa, untuk mencapai tujuan organisasi tergantung pada penentuan kebutuhan dan keinginan pasar sasaran (target market) dan memuaskan pelanggan secara lebih efektif dan efisien dari pada yang dilakukan pesaing (Kotler dan Armstrong, 2009: 23). Sudah sewajarnya jika segala kegiatan perusahaan harus dicurahkan untuk mengetahui apa yang diinginkan konsumen kemudian memuaskan konsumen tersebut dan pada akhirnya perusahaan bertujuan memperoleh laba.

\section{Pengertian Marketing Mix (Bauran Pemasaran)}

Marketing Mix (Bauran pemasaran) adalah unsur atau elemen internal penting yang membentuk program pemasaran sebuah organisasi.Bauran pemasaran merupakan salah satu konsep universal yang telah dikembangkan dalam pemasaran (Payne, 2009: 31). Sedangkan menurut Gilbert A. Churchil (2005: 8) dalam Rahmawati (2009: 12), "Marketing Mix (bauran pemasaran) atau 4P yaitu pruduk (product) atau jasa, harga (price), tempat (place) atausaluran distribusi, dan promosi (promotion) atau bauran komunikasi". Dari berbagai definisi diatas bauran pemasaran mempunyai fungsi yang amat penting dalam mencapai keberhasilan perusahaan.

Menurut Nitisemito (2008: 57) dalam menetapkan bauran pemasaran harus berpegang pada prinsip ekonomis yaitu untuk mencapai hasil tertentu diusahakan pengorbanan sekecil-kecilnya, atau dengan pengorbanan tertentu diusahakan hasil sebesar-besarnya.

1. Marketing mix harus seimbang

Dalam melaksanakan marketing mix secara umum haruslah diusahakan dalam keadaan yang seimbang.Seimbang disini adalah dalam keadaan keseimbangan yang sebaik mungkin, meskipun secara khusus tekanan dapat berbeda.

2. Marketing mix tidak boleh statis

Banyak perusahaan yang telah menetapkan marketing mix tanpa pernah melakukan peninjauan kembali.Dengan demikian kemungkinan situasi dan kondisi sudah berubah, sehingga marketing mix yang ditetapkan sudah tidak cocok lagi.Oleh karena itulah marketing mix tidak boleh bersifat statis, tapi harus bersifat dinamis.

3. Marketing mix tidak boleh meniru

Dalam melaksanakan marketing mix kita tidak boleh meniru-niru perusahaan-perusahaan yang lain, sebab situasi dan kondisi dari perusahaan yang satu dengan yang lain tidaklah mesti sama.

4. Marketing mix harus bertujuan jangka panjang

Dalam melaksanakan marketing mix, maka sebaiknya diusahakan mencapai tujuan jangka panjang. Hal ini tidak berarti tujuan jangka pendek boleh diabaikan. Tujuan jangka pendek ada pula yang dipakai untuk mencapai tujuan jangka panjang. 
5. Marketing mix harus disesuaikan dengan kondisi dan keadaan perusahaan

Dalam menetapkan marketing mix, maka persahaan dapat terlebih dahulu menetapkan target omzet penjualan yang ingin dicapai. Akan tetapi dalam keadaan dana yang terbatas maka marketing mix ditetapkan terlebih dahulu dan baru kemudian menetapkan target penjualan yang mungkin dicapai.

6. Marketing mix harus didasarkan pengalaman

\section{Keputusan Pembelian}

Keputusan pembelian merupakan kegiatan individu yang secara langsung terlibat dalam pengambilan keputusan untuk melakukan pembelian terhadap produk yang ditawarkan oleh penjual. Kotler dan Amstrong (2011:129) keputusan pembelian konsumen adalah perilaku pembelian akhir dari konsumen baik individual maupun rumah tangga, yang membeli barang-branag dan jasa untuk konsumsi pribadi. Suatu produk dapat dikatakan telah dikonsumsi oleh konsumen apabila produk tersebut telah diputuskan untuk dibeli. Keputusan untuk membeli dipengaruhi oleh nilai produk yang dievaluasi.Bila manfaat yang dirasakan lebih besar dibandingkan pengorbanan untuk mendapatkannya maka dorongan untuk membelinya semakin tinggi.

\section{Faktor-Faktor Yang Mempengaruhi (Marketing Mix) Bauran Pemasaran Terhadap Keputusan Pembelian Konsumen}

Marketing Mix atau bauran pemasaran merupakan faktor penting dalam keputusan pembelian konsumen, terdiri dari produk, harga dan promosi. Faktor ini yang akan diteliti sebagai faktor yang mempengaruhi keputusan pembelian. Menurut Kotler dan Amstrong (2009:18), bauran pemasaran adalah seperangkat alat pemasaran yang digunakan perusahaan untuk terus menerus mencapai tujuan pemasarannya dipasar sasaran. Alat-alat pemasaran yang dapat digunakan untuk mempengaruhi pembeli antara lain :

1) Produk

Produk dapat memberikan rangsangan padakonsumen sehingga dapat membangkitkan selera atau minat untuk membeli. Kotler dan Amstrong (2009: 431), berpendapat produk sebagai sesuatu yang dapat ditawarkan ke suatu untuk memenuhi keinginan atau kebutuhan.Selain itu produk juga memiliki berbagai atribut. Menurut Tjiptono (2008:103), atribut produk adalah unsur-unsur produk yang dipandang penting oleh konsumen dan dijadikan dasar pengambilan keputusan pembelian. Atribut produk merupakan suatu karakteristik spesifik dari produk yang memberikan manfaat penting bagi konsumen dan dijadikan dasar pengambilan keputusan pembelian. Produk adalah sebuah benda atau pelayanan yang ditawarkan untuk memenuhi kebutuhan dan kepuasan konsumen, baik itu kebutuhan primer atau kebutuhan sekunder (Putri,2012: 12).

2) Harga

Harga adalah satuan moneter atau ukuran lainnya (termasuk barang dan jasa lainnya) yang ditukarkan agar memperoleh hak kepemilikan atau penggunaan suatu barang atau jasa (Tjiptono, 2008: 151). Dalam kebijakan harga manajemen harus menentukan harga dasar dari produknya, kemudian menentukan kebijaksanaan menyangkut potongan harga, pembayaran karyawan dan hal-hal lain yang berhubungan dengan harga.

3) Promosi

Promosi adalah arus informasi atau persuasi satu arah yang dibuat untuk mengarahkan seseorang atau organisasi kepada tindakan yang menciptakan pertukaran dalam pemasaran (Swastha dan Sukotjo, 2002: 222).Tujuan dari promosi adalah untuk meningkatkan penjualan atau keuntungan. Menurut Kotler dan Amstrong (2009:365) Untuk mempengaruhi perilaku konsumen, perusahaan dapat menggunakan strategi promosi.Perusahaan mempromosikan produk agar konsumen dapat mengenali produk dan untuk tujuan agar konsumen terbaik untuk melakukan keputusan pembelian.

\section{METODE PENELITIAN}

\section{Lokasi Penelitian}

Penelitian dilaksanakan di wilayah Kota Banda Aceh. Penelitian ini akan membahas mengenai keputusan pembelian konsumen terhadap parfum Minyeuk Pret di Kota Banda Aceh. Pembahasan dari penelitian ini hanya terbatas pada masalah pengaruh bauran pemasaran terhadap keputusan konsumen dalam membeli parfum Minyeuk Pret. Dalam hal ini parfum Minyeuk Pret yang dimaksud yaitu parfum kreasi dari anak muda Aceh yang beraroma khas Aceh,yaitu coffee, meulu dan seulanga. 


\section{Analisis Data}

Dalam menganalisis data untuk penelitian ini digunakan regresi linear berganda (Multiple Linear Regression) dengan bentuk interaksi keseluruhan sebagai berikut :

$$
Y=a+\beta 1 X 1+\beta 2 X 2+\beta 3 X 3+e
$$

Untuk mengetahui hubungan antara variabel terikat dan variabel bebas digunakan analisis korelasi $(R)$ dan determinasi (R2).

\section{Rancangan Penelitian}

Penelitian dilakukan secara kuantitatif dengan rancangan riset deskriptif. Desain deskriptif bertujuan untuk menjelaskan sesuatu, seperti: menjelaskan karakteristik suatu kelompok yang relevan, mengestimasi persentase dalam populasi tertentu yang menunjukkan perilaku tertentu, mengetahui persepsi atas karakteristik produk, mengetahui berapa besar hubungan suatu variabel dan untuk mengetahui prediksi spesifik (Malhotra, 2007). Dalam penelitian ini, peneliti ingin menganalisa hubungan antara variabel (Marketing Mix) bauran pemasaran terhadap keputusan pembelian.

\section{Teknik Pengumpulan Data}

Jenis data yang digunakan adalah data primer dan data sekunder. Data primer dengan melakukan wawancara terhadap responden serta menggunakan daftar pertanyaan yang sudah dipersiapkan sebelumnya. Data sekunder adalah data yang diperoleh dari sumber tidak langsung yaitu manajemen Minyeuk Pret dan pustaka yang dapat membantu dalam pembahasan permasalahan yang ada. Responden dalam penelitian ini adalah konsumen Minyeuk Pret yang ada di Kota Banda Aceh. Jumlah responden yang diambil sebagai sampel yaitu 100 responden dengan menggunakan teknik convinience sampling.

\section{HASIL PENELITIAN DAN PEMBAHASAN}

\section{Gambaran Umum Minyeuk Pret}

Minyeuk Pret merupakan salah satu produk kearifan lokal daerah Aceh yang memperkenalkan beberapa aroma khas dari Aceh yang dibuat dalam bentuk parfum. Hal ini bertujuan untuk mengangkat budaya, sejarah dan nilai-nilai daerah Aceh kepada dunia melalui parfum beraroma khas Aceh. Mulai merintis usaha pada tahun 2014. Dengan menggunakan bahan baku nilam terbaik di dunia yang didapatkan dari perkebunan nilam Aceh.

Minyeuk Pret mengeluarkan tiga produk pertamanya dengan varian bunga dan kopi khas Aceh. Pada saat pertama kali diluncurkan Minyeuk Pret mendapat capaian yang fantastis dengan angka pemesanan mencapai 1.683 unit. Parfum Minyeuk Pret memiliki lebih dari 15\% pure essence, sehingga masuk ke dalam kategori eau de parfum. Jenis EDP ini memiliki ketahanan aroma yang kuat,hingga satu sampai dua hari pemakaian. Kandungannya terdiri dari alcohol, bibit, minyak nilam, dan bahan ekstrak rahasia perusahaan. Saat ini Minyeuk Pret semakin dikembangkan dan ada beberapa varian baru juga yang dihasilkan seperti aroma bunga Jeumpa. Kantor pemasaran Minyeuk Pret terletak di Jalan Wedana No. 104 Lam Ara, Ketapang II, Kecamatan Banda Raya Kota Banda Aceh, Provinsi Aceh.

\section{Analisis Faktor-Faktor Yang Mempengaruhi Pengambilan Keputusan Pembelian Minyeuk Pret di Kota Banda Aceh}

Sesuai dengan peralatan analisis data yang digunakan untuk mengetahui hubungan fungsional antara variabel yang diteliti dalam penelitian ini, dengan menggunakan analisis regresi linier berganda. Untuk melihat pengambilan keputusan pembelian Minyeuk Pret di Kota Banda Aceh, maka perlu mengetahui pengaruh produk, harga dan promosi terhadap pengambilan keputusan pembelian Minyeuk Pret di Kota Banda Aceh. Hal ini ditunjukkan oleh nilai koefisien regresi masing-masing variabel seperti terlihat pada Tabel dibawah 
Tabel 1. Nilai Koefisien RegresiMasing-masing Variabel Independen

\begin{tabular}{|c|c|c|c|c|c|c|c|}
\hline \multicolumn{8}{|c|}{ Coefficients $^{a}$} \\
\hline \multirow[b]{2}{*}{ Model } & \multicolumn{2}{|c|}{$\begin{array}{l}\text { Unstandar } \\
\text { dized Coefficients }\end{array}$} & \multirow{2}{*}{$\begin{array}{c}\text { Standardized } \\
\text { Coefficients }\end{array}$} & \multirow[t]{2}{*}{ t } & \multirow[t]{2}{*}{ Sig. } & \multicolumn{2}{|c|}{ Collinearity Statistics } \\
\hline & B & Std. Error & & & & Tolerance & VIF \\
\hline 1 Constant) & .347 & 1.590 & & 2.218 & .003 & & \\
\hline Produk & .143 & .108 & .138 & 2.403 & .002 & 259 & 3.859 \\
\hline Harga & .394 & .080 & .350 & 4.926 & .000 & 466 & 2.146 \\
\hline Promosi & .799 & .132 & .511 & 6.062 & .000 & .333 & 3.007 \\
\hline
\end{tabular}

Dependent Variabel: KeputusanPembelian

Sumber: Data Primer (Diolah).

Berdasarkan Tabel diatas maka persamaan regresi linier berganda yang memperlihatkan pengambilan keputusan pembelian Minyeuk Pret di Kota Banda Aceh sebagai fungsi dari produk, harga dan promosi, dapat diformulasikan dalam persamaan berikut:

$$
Y=0,347+0,143 X_{1}+0,394 X_{2}+0,173 X_{3}
$$

\section{Pembuktian Hipotesis}

1). Uji F (Simultan)

Hasil pengujian statistik menunjukkan nilai $F_{\text {nitung }}$ sebesar 83,224 nilai $F_{\text {tabel }}$ pada tingkat keyakinan 95 persen menunjukkan angka sebesar 2,473 . Karena nilai $F_{\text {hitung }}>F_{\text {tabel }}(83,224>2,473)$, artinya produk $\left(X_{1}\right)$, harga $\left(\mathrm{X}_{2}\right)$, dan promosi $\left(\mathrm{X}_{3}\right)$ secara simultan berpengaruh signifikan terhadap pengambilan keputusan pembelian Minyeuk Pret di Kota Banda Aceh, sehingga hipotesis Ha diterima.

\section{2). Ujit (Parsial)}

Uji $t$ (parsial) dilakukan untuk mencari pengaruh variabel bebas terhadap variabel terikat dalam persamaan regresi uji parsial variabel lain dianggap konstan. Uji t dilakukan dengan membandingkan thitung dengan tabel, yaitu:

1. Hipotesis pertama pada variabel $\operatorname{prooduk}\left(X_{1}\right)$ menunjukkan nilai $t_{\text {nitung }}>t_{\text {tabel }}(2,403>1,985)$, artinya produk secara parsial berpengaruh signifikan terhadap pengambilan keputusan pembelian Minyeuk Pret di Kota Banda Aceh, sehingga hipotesis pertama Ha diterima.

2. Hipotesis kedua pada variabel harga $\left(X_{2}\right)$ menunjukkan nilai $t_{\text {nitung }}>t_{\text {tabel }}(4,926>1,985)$, artinya harga secara parsial berpengaruh signifikan terhadap pengambilan keputusan pembelian Minyeuk Pret di Kota Banda Aceh, sehingga hipotesis kedua Ha diterima.

3. Hipotesis keempat pada variabel promosi $\left(X_{3}\right)$ menunjukkan nilai thitung $>t_{\text {tabel }}(6,062>1,985)$, artinya promosi secara parsial berpengaruh signifikan terhadap pengambilan keputusan pembelian Minyeuk Pret di Kota Banda Aceh, sehingga hipotesis ketiga Ha diterima.

Tabel 2.1

Untuk lebih jelasnya mengenai hasil uji $\mathrm{F}$ dan uji t sebagai tolok ukur pengujian hipotesis dapat dilihat 
Tabel 2. Ringkasan Pengujian Hipotesis

\begin{tabular}{|c|c|c|l|}
\hline \multirow{2}{*}{ Bentuk Pengujian } & \multicolumn{2}{|c|}{ Nilai Statistik } & \multirow{2}{*}{ Keterangan } \\
\cline { 2 - 3 } & Fhitung & Ftabel & \\
\hline Pengujian secara simultan & 83,224 & 2,473 & Ketiga variabel berpengaruh signifikan (hipotesis Ha diterima). \\
\hline Pengujian secara parsial & thitung & tabel & \\
\hline Produk $\left(X_{1}\right)$ & 2,403 & 1,985 & Produk berpengaruh signifikan \\
\hline Harga $\left(X_{2}\right)$ & 4,926 & 1,985 & Harga berpengaruh signifikan \\
\hline Promosi $\left(X_{3}\right)$ & 6,062 & 1,985 & Promosi berpengaruh signifikan \\
\hline
\end{tabular}

Sumber: Data Primer (Diolah).

Berdasarkan Tabel 2.1 bahwa baik secara simultan maupun secara parsial produk, harga dan promosi berpengaruh signifikan terhadap pengambilan keputusan pembelian Minyeuk Pret di Kota Banda Aceh. Hal ini berarti bahwa produk, harga dan promosi secara nyata dapat meningkatkan pengambilan keputusan pembelian Minyeuk Pret di Kota Banda Aceh.

\section{KESIMPULAN}

Berdasarkan hasil penelitian dan pembahasan, maka dapat disimpulkan beberapa hal sebagai berikut:

1. Nilai Fhitung $>$ Ftabel $(83,224>2,473)$, artinya produk $(X 1)$, harga $(X 2)$, dan promosi $(X 3)$ secara simultan berpengaruh signifikan terhadap pengambilan keputusan pembelian Minyeuk Pret di Kota Banda Aceh.

2. Nilai thitung>ttabel $(2,403>1,985)$, artinya produk secara parsial berpengaruh signifikan terhadap pengambilan keputusan pembelian Minyeuk Pret di Kota Banda Aceh.

3. Nilai thitung $>$ ttabel $(4,926>1,985)$, artinya harga secara parsial berpengaruh signifikan terhadap pengambilan keputusan pembelian Minyeuk Pret di Kota Banda Aceh.

4. Nilai thitung>ttabel $(6,062>1,985)$, artinya promosi secara parsial berpengaruh signifikan terhadap pengambilan keputusan pembelian Minyeuk Pret di Kota Banda Aceh.

5. Nilai koefisien korelasi (R) menunjukkan bahwa hubungan (korelasi) antara variabel bebas dengan variabel terikat sebesar 0,886 atau 88,6\%, artinya pengambilan keputusan pembelian Minyeuk Pret di Kota Banda Aceh mempunyai hubungan yang sangat kuat dan positif dengan produk (X1), harga (X2), dan promosi (X3).

6. Nilai koefisien determinasi (R2) sebesar 0,785 , artinya sebesar $78,5 \%$ perubahan dalam variabel terikat yaitu keputusan pembelian dapat dijelaskan oleh perubahan dalam variabel produk (X1), harga (X2) dan promosi (X3) dan sisanya yaitu sebesar $21,5 \%$ dijelaskan oleh variabel lain diluar dari pada penelitian ini, misalnya citra merek, perilaku konsumen dan lain-lain.

\section{REFERENSI}

[1] Kotler, Philip. (2002). Dasar-Dasar Pemasaran.CV Intermedia : Jakarta

[2] Kotler, Philip. (2009). Manajemen Pemasaran.Jilid I dan II. Edisi Milenium Prehallindo. Jakarta.

[3] Kotler, Philip dan Amstrong, Gary.(2009). Prinsip-Prinsip Pemasaran, Jilid I Edisi Kedelapan.Erlangga. Jakarta.

[4] Lamb, Hair dan McDaniel.(2001). Pemasaran.Buku 1. Salemba Empat : Jakarta.

[5] Mowen, John C. (2002). Perilaku Konsumen. Jilid 1. Edisi Kelima. Erlangga : Jakarta.

[6] Machfoedz, Mahmud. (2007). Pengantar Bisnis Modern.Edisi 1. PT ANDI. Yogyakarta.

[7] Payne, Adrian. (2009). The Essence Of Service Marketing Pemasaran Jasa. Alih bahasa: Fandy Tjiptono. Yogyakarta: Andi.

[8] Swastha DH, Basu. (2002). Azas-Azas Marketing.Edisi 3.Liberty : Yogyakarta.

[9] Sugiyono.(2007). Metode Penelitian Bisnis.Alfabeta : Bandung. 
[10] Suliyanto.(2006). Metode Riset Bisnis.Yogyakarta

[11] Suharsimi, Arikunto.(2006) Prosedur Penelitian Suatu Pendekatan Praktik. Edisi Revisi VI. PT. Rineka Cipa. Jakarta.

[12] Sumarwan, Ujang. (2007). Perilaku Konsumen.Cetakan Kedua. Ghalia Indonesia.Bogor Selatan.

[13] Tjiptono, Fandy. (2008). Strategi Pemasaran.Edisi 2. Andy Offset : Yogyakarta. 